\title{
Building Zones of Peace Project: Analysis of the Perception of Girls and Adolescents about Violence and Peace in the Community of Guararí
}

\section{Proyecto Construcción de Zonas de Paz: Análisis de la percepción de las niñas y adolescentes sobre la violencia y la paz en la comunidad de Guararí}

\author{
Sharon López-Céspedes \\ Coordinator Master's Programme in Human Rigths \\ Silvia Elena Guzmán-Sierra \\ Academic Assistant \\ Instituto de Estudios Latinoamericanos \\ Universidad Nacional, Costa Rica \\ Received: 25/01/2019 \\ Accepted: 25/02/2019 \\ DOI: https: //doi.org/10.15359/tdna.35-65.14
}

\begin{abstract}
Building Zones of Peace (BZP)

Project: Analysis of the perception of girls and adolescents about violence and peace in the community of Guarari is part of the efforts made by the Universidad Nacional, through the Office of Extension, in carrying out the "Cultural Cities" project, which together with the Municipality of Heredia and the Civic Center
\end{abstract}

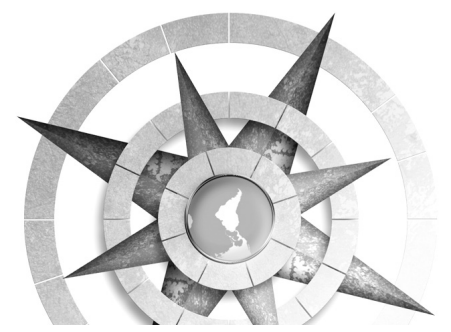

for Peace (CCP) of Guararí, articulate processes for the prevention of violence and the construction of peace, focused mainly on children, adolescents and youth at risk.

Keywords: Zones of Peace, violence and peace, prevention of violence, Guararí, Instituto de Estudios Latinoamericanos (IDELA).

\section{Resumen}

El proyecto Construcción de Zonas de Paz: análisis de la percepción de la niñez y la adolescencia sobre la violencia y la paz en la comunidad de Guararí se enmarca en los esfuerzos que la Universidad Nacional, a través de la Vicerrectoría de Extensión, viene realizando en el Proyecto Ciudades Culturales, 
las cuales, en conjunto con la Municipalidad de Heredia y el Centro Cívico por la $\mathrm{Paz}$ (CCP) de Guararí, articulan procesos para la prevención de la violencia y la construcción de la paz enfocados, principalmente, en la niñez, la adolescencia y la juventud en riesgo.

Palabras clave: Zonas de paz, violencia y paz, prevención de la violencia, Guararí, Instituto de Estudios Latinoamericanos

\section{Resumo}

O Projeto de Construção de Zonas de Paz: A análise da percepção de crianças e adolescentes sobre violência e paz na comunidade de Guarari faz parte dos esforços que a Universidade Nacional, através do Vicertório de Extensão, está realizando no Projeto Cidades Culturais, que, juntamente com a Prefeitura de Heredia e o Centro Cívico da Paz (CCP) de Guararí, articulam processos para a prevenção da violência e a construção da paz voltados principalmente para crianças, adolescentes e jovens em situação de risco.

Palavras chave: Zonas de paz, violência e paz, prevenção da violência, Guarari, Instituto de Estudos Latino-Americanos

Hand in hand with the Office of Extension of Universidad Nacional, the Municipality de Heredia and the Civic Center for Peace of Guararí, the Institute of Latin American Studies, known in Spanish as IDELA, being a regional reference in postgraduate studies in human rights and education for peace, privileges spaces where it can lead projects that, in addition to promoting the construction of knowledge and the experiential learning of its students, generate a positive impact in the communities, particularly, in those population groups that are in situations of greater vulnerability, as it is the case of the primary population of the present proposal for the integral attention of conflict, violence and construction of social peace of this project.

The community of Guarari is located in the district of San Francisco of in the Central Canton of the province of Heredia, and is considered the most socially vulnerable area, as a result of the development of social housing projects which, in turn, unleashes a series of factors such as social segregation due to the concentration of families with low socioeconomic income, deficient government presence, and the increase of migrant population, among others ${ }^{1}$.

As a result, a series of social pathologies have been arisen, such as problems associated with drug trafficking and consumption, delinquency, crime, overcrowding, teenage pregnancies, lack of decent housing, violence in the family context and high school dropout rates.

1 See Chávez, Diagnóstico. Centro Cívico por la Paz Guararí. Documento interno de trabajo. (In Spanish). 
This scenario has led Guararí to be ranked among the areas with the highest rates of violence in the country, reason why a CCP was built in the area, which proposes a local intervention strategy for the prevention of violence. Accordingly, a CCP prioritizes the attention of boys, girls and adolescent population, with an age range from 13 to 19 of outmost attention priority.

Consequently, the project named Construyendo Zonas de Paz (translated Building Zones of Peace), aims to strengthen the capacities for the transformation of conflicts, contributing to the mitigation of violence and the construction of peace, contemplating a comprehensive pedagogical strategy from a peace and human rights educational approach, focused on working with adolescent-young populations.

In a theoretical and practical sense, it is understood that both peace and violence are not permanent or static states, rather they are both social processes intertwined in a complex way crossed by multiple factors and contexts.

In such complexity we distinguish, following Johan Galtung's theories, three forms of violence, namely:

- direct violence which has direct material implications either on bodies, nature or property;
- structural violence that results in institutionalized violence (institutions, political systems, social organization); and

- cultural violence which is the umbrella framework under which the previous forms of violence are legitimized, justified and normalized.

On the other hand, peace is understood as a process that is constructed on a daily basis, from the creativity of people and it can be built at the direct, structural or cultural levels. Peace is not the absolute absence of conflict or a permanent state, but rather life options built individually and/or collectively that confront violence to create autonomous alternatives of dignity. Thus, peace work for peace can be translated as spaces that offer the possibility of building cultural, social and community dialogues, spaces where all people have a voice.

The construction of peaceful forms of coexistence, in spaces where violence has been installed and normalized, is complex, and requires the analysis of its multiple factors. Peace-building processes have as a challenge to develop and promote creative-transformative approaches before a system of selfperpetuating violent patterns, patterns reproduced by multifactorial and no lineal elements, in our social relations. In this sense, our intention is for BZP participants to understand each 
other as transforming agents of the conditions of violence installed in their community, from the centrality of their relationships and from their imaginative and creative capabilities.

With these considerations a participatory process was built in which the participants of the Building Zones of Peace Project, as well as girls from the project Liga Fem: the court for us of Sepro Joven $^{2}$ (in total 18 girls and adolescents between 7 and 16 years of age), accompanied by six students of IDELA's Human Rights and Education for Peace Master's programme, and the facilitator team of Silvia Guzman y Sharon Lopez, undertook a process to capture through photography what the participants identified as zones of peace and violence in their community.

At first, IDELA master's programme students facilitated two workshops with participants to analyze and reflect on concepts of direct, structural and cultural violence. Secondly, participants made a mapping of their community identifying those elements that generated peace or produced violence for them. In a third moment, having already identified the different places, participants and facilitators conducted

2 This alliance comes as a response to the interest of linking participants from different projects that were carried out during 2017 in the Civic Center for Peace (CCP) of the community of Guararí, Heredia, Costa Rica a fieldwork where they took photographs of the places identified in the cartographies. The artistic product of this experience was a photography exhibition denominated Peace and Violence in Our Community ${ }^{3}$. The selection of twelve photographs was made from more than two hundred photos taken by all eighteen participants, in a participatory, reflective and dialogical process in which they expressed their perceptions of violence and peace and chose those pictures that better represented their ideas and feelings.

From this work three results are gathered referring to those forms of violence identified by the participants, namely: violence against nature (pollution) and the use of public spaces, socio-economic violence (inequality and poverty) and violence against women. The participants also recognize forms of peace wherein clearly manifested as the bond with nature, as well as social inclusion and recreational spaces, all generating the possibility for constructing their own peace. An analysis of these three forms of violence and their impact on this population, as well as the construction of forms

3 Project newsletter written by the participants: https://es.calameo.com/read/ $0052319187323027368 \mathrm{cb}$

Photography exhibition poster: https://www.facebook.com /infolatino.idela/photos/a 972486082832286.1073741828. $972427676171460 / 1578810378866517$ $/$ type $=3 \&$ theater 
of peace, will be discussed below.

Participating individuals, through their field research, pinpointed different areas in the community characterized by pollution, which are vacant lots, streams, sidewalks and storm water sewer conduits. Visiting these places allowed participants to come up with three important reflections.

First of all, participants analyze the problem of solid waste, and how its accumulation on sidewalks leads to sewer conduit clogs that causes flooding during the rainy season, provoking, consequently, economic issues to the families. Furthermore, it is evident that contamination in their community by solid waste pollutes nearby rivers eliminating possible sources of potable water. This analysis motivated participants to reflect on the interdependence and complementarity of human rights, as it is clear to them that violence against nature limits their right to a healthy environment, adequate shelter and clean water, and how pollution creates economic repercussions for their families.

A second reflection refers to the responsibility for waste management. On one hand, participants underline the responsibility of the local government in the management of solid waste collection. In this regard, they point out two deficient factors, the first relates to the frequency of weekly collection service and the second to the quality of the service itself. Participants claim that collection is done in a hasty manner and that sometimes waste is left uncollected accumulating on the sidewalks and streets; however, they also point out the responsibility of citizens for managing their waste incorrectly. According to their opinions, some people in the community do not classify their waste, either they dispose it in proper waste bins or leave them within reach of animals that scatter the garbage. Participants conclude that although municipal services are not the most adequate, much of the contamination could be avoided if citizens acted in a more responsible manner.

A third reflection, rather than an analysis of reality or a denunciation of the responsibility concerning violence against nature, is a claim full of hope. Participants denote the abandoned and idle public spaces and denounce the lack of appropriate public spaces, particularly for youth recreation. One of the female participants even delves more into criticism and refers to how adolescents lack public spaces for recreation, enjoyment and socialization, and points out how the few places that exist for this purpose are intended for children only, leaving the adolescent population expelled in a normative and mainly social manner from these spaces. This claim demonstrates how the cooptation of a right, the right to a healthy environment, hinders access to another right, the right to leisure and recreation. 
We are dealing with what Steven Flusty describes as "prohibitory spaces [...], designed to intercept and reject or filter those who aspire to use them"

The use of public space is dually inaccessible for adolescents, in the first place, because of the disuse and abandonment of some areas and, secondly, because possible recreation spaces are understood as being exclusive for people belonging to a certain age group. The possibilities of socio-spatial identification that people may have with community spaces is extremely reduced as there is no experimentation of the public space as one of their own, limiting social relations to private and family sphere, recognized by participants as spaces of peace (especially their bedrooms). Such disconnection with community space could lead to disengagement from community problems and needs.

The reduction of public spaces is also a reduction of political and communal spaces ${ }^{5}$ therefore, these spaces that

4 See Bauman, La Globalización, consecuencias $h u$. manas, p. 31. (In Spanish)

5 The philosopher Zigmund Bauman, points out that in the globalizing contemporaneity, public spaces, agoras and forums in their diverse expressions [...] followed the elite by freeing themselves of their local anchors; they are the first to be deterritorialized and put out of reach of the communicative capacity of the human factor of a locality and its residents. Far from generating communities, local populations are like bundles of loose ends. (Bauman, 2001, page 35) could facilitate an understanding of the meaning of an active citizenship is left out of reach of young people. Public spaces are then residual and impotent. However, in view of this situation, participants are filled with hope and see in community organization, reclamation and embellishment of public spaces a possibility for the enjoyment of their rights. They recognize themselves as subjects of rights, and as such, claim the universality of rights, understanding universality in terms of the "strengthening of individuals, groups and organizations when constructing an action framework that would allow all subjects the creation of conditions that guarantee the equal access to material and immaterial goods that make life worth living" .

The analysis of violence against nature made by the BZP participants of Guarari community recalls the premise that human rights are universal and, therefore, indivisible from each other, but also that human rights are a constant fight for the dignity of people, which materialize in opportunities and conditions for access to goods and services

The proposals for embellishing the community made by participants are an example of a struggle full of hope and creativity. We need, then, to rebuild spaces or zones of informality that propose alternative and anti-systemic

6 See Herrera Flores, La Reinvención de los Derechos Humanos, p. 13 (In Spanish) 
visions that aim to build the social and cultural bases of a new hegemony. For this reason, in order to know and practice the rights, it is necessary to situate them in those symbolic spaces where power relations place individuals on different levels from which to achieve dignity.

Perhaps socio-economic violence for a community like Guararí is one of the most obvious and day-to-day forms of violence in the lives of its inhabitants, however, a phenomenon as structural poverty is such a complex one that a simple investigation like this one put forth by the present peacebuilders bring out their most subjective consequences.

A first element that draws attention is how participants stratify the neighborhoods within the community depending on socioeconomic status. Participants make a spontaneous exercise of allocating cultural stigmas imposed on Guarari's inhabitants by external citizens of Heredia and countrywide, to people living in certain specific neighborhoods of Guarari but not necessarily to the entire Guararí community. An example of this is the consideration by some of Guarari's own inhabitants of La Milpa as being the only violent area of the entire community, thus falling in the same sense of generalized labeling of which they are victims themselves.
An analysis of these stigmas and the visibility of socioeconomic differences between them allows the generation of awareness about inequality and an analysis of its causes and consequences, which is developed, mainly, around the right to decent housing, as a human right.

Another element that stands out is the socio-affective links created by some of the participants to specific institutions that in the past have provided them with financial aid to meet their needs. These institutions take a fundamental position in their life histories because it is understood that if it were not for certain aids their right to education or food could not have been fulfilled. It is important to point out the existence of an age-related differentiation as pertains to the socio-affective link created between participants and government institutions: younger participants show greater trust towards assistance institutions such as the Mixed Institute of Social Assistance (IMAS) and at the same time are faithful believers in community self-management; meanwhile, older participants show less faith in institutions, but nonetheless, delegate to them, without optimism, social and community responsibilities.

The analysis of socioeconomic violence is extremely complex and is loaded with the sensitivity that comes from a life of negative cultural impositions dumped on the population of Guararí. However,

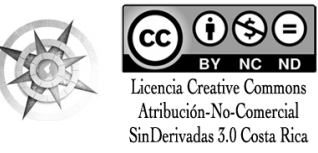


in resistance to this violence, participants are aware that their community, despite being marked by violence and inequality, is a community "with good people" and diverse. Through a benevolent exercise, participants value the differences by taking conscience of the immateriality, abstraction and absolutization of social stigmas and prejudices, and in light of this, participants validate the dignity of diversity recognizing themselves as peripheral observers and from that standpoint they enunciate.

For this reason, the human rights complexity nature requests us to put ourselves in the periphery. There is only one center, and that which does not coincide with it, is abandoned to marginality. On the contrary, there are many peripheries. In reality, all is peripheral if we accept that nothing is pure and that all is related.

Thus, the task is, from the otherness' standpoint, to reflect on and find material and immaterial local answers for the construction of dignified identities and lives. In this respect, one of the main reflections made by the participants is that, despite discrimination suffered by them or their families due to their migrant origin or socioeconomic status, the apparent differences perceived by others (community outsiders) can be mended via intercultural dialogues and empathy.
Participants partake denunciation from mutual recognition, from the impure and the mixed, they understand the diversity that entails the inter-subjective possibility of dignification, and thus, understand that socioeconomic violence (hierarchy) of the structure of power that imposes differences (narratives of community stratification) but in the recognition of dignification as well as the differences that exist lies the possibility of bonding for the construction of peace in their community and the elimination of social stigmas associated with the inhabitants of Guararí.

Unlike the most practical conclusions regarding the ability of direct action opposing violence against nature and misuse of public spaces, participants are aware that their capacity of action against socio-economic violence is substantially diminished, nonetheless, the raise in awareness and the stance taken by the participants is fundamental; understanding that in view of structural violence denouncing inequalities and finding local ways to succumb the violent structure from imposing itself on the construction of the subject's identity, is in itself a revolutionary exercise.

On the other hand, the various ways in which violence against women transverses participants' lives, has been an element recurrently brought to discussion throughout the process, sharing situations of violence in their homes, in 
their communities and at school, lived by male and female participants, by their peers or relatives, including street harassment, school bullying, physical, psychological, patrimonial.and sexual abuse.

Properly, during the process of elaborating the symbolic cartography of violence, differences are reflected in the way in which participants, both girls and female and male adolescents, understand and reflect on violence against women, according to their ages and gender.

In general terms, both groups describe the inequality between men and women in terms of the roles played at the domestic level, where both groups identify the mother as the person who assumes the burden of housekeeping, caring for children, etc., situation which is, in fact, the case of various adolescent female participants, as will be pointed out later.

There is also the complaint of unavailability of spaces, especially for girls and female adolescents, for practicing sports. In the case of girls from Sepro Joven's project, Liga Fem: the court for us, it is necessary to highlight that the experienced lived by these girls has visibly contributed to self-empowerment processes. On the one hand, the girls manage to identify (and openly express it) the prejudices that women face when it comes to soccer (football) or other sports. On the other hand, and even more rewarding, it is to see them establish rules, share leadership, and position themselves critically before identified community problems.

Additionally, we find in the case of female adolescents, not only the complaint of reduced or no space availability for women to practice soccer (football), but also facing harassment by their peers, as told by one of the participant, who shared her experience at school, where her sexual identity was repeatedly questioned due to her interest in practicing this sport.

These sexist manifestations also occur inversely, such is the case of one of the male adolescents who tells us that due to him playing the lyre in the school band he is bothered by some of his peers, as the lyre is considered an instrument for "girls". These examples presented by the participants reflect the discrimination suffered by sexism rooted in our homes, schools and communities. Such sexism is understood as "the set of attitudes and beliefs that convert an individual's sex or gender in the determining factor to attribute or stop recognizing their value, abilities or particular merits"?

Other subtler forms of structural violence experienced by the participating adolescents were identified by project's

7 See Obando, Educación género sensitiva: Paradigma de una cultura de paz, p. 229 (In Spanish) 
facilitators, not only in terms of the narratives of participants, but in some situations that were presented throughout the process. An example of this was the justification of the absences to the sessions, which in the case of female adolescents, were mostly legitimized in terms of their "domestic responsibilities", as they had to stay home taking care of their younger siblings, or housework while their mom went to work or do errands. Conversely, in the case of men, their absences were justified by reason of other activities, such as soccer (football), school band, or because of economic situations, "my mother did not have money for the bus ticket", for example.

The domestic burden that is transferred to girls and female adolescents interferes in their full development, not only by limiting their participation in non-formal education programs such as this project, but also by affecting their educational process, as it is more frequent for girls or female adolescents to assume these household responsibilities, consequently missing school, lacking time and energy to study, do their homework, etc. In this way, the right to education ${ }^{8}$ is violated, having a negative

8 UNESCO points out that "education empowers women to overcome discrimination. Girls and young women who have received education know their rights better, and have greater confidence and freedom to make decisions that affect their lives, improve their own and their children's health and impact on the integral development of women.

In addition to what has been mentioned in previous paragraphs, it is evident that the participants, although recognizing forms of violence against women such as sexual violence or street harassment, also, in their interpretations and reflections, evidence learned patterns and discourses of misogynistic and patriarchal tinge, that justify that violence. For example, some of the female participants consider that the way females dress "causes" men to harass them in the street.

Among male participants there were those who pointed out that men's jealousy, as well as alcohol consumption, are causes of physical and psychological abuse, even highlighting cases in which men leave women locked in their houses, beating them if they leave.

The multiple forms of violence experienced by the participants, is enhanced as a result of the overcrowding in which they live, house structures, and the proximity between houses, as one of the participants points out, allows him to hear screams, abusive treatment,

survival chances, and increase their job prospects. Getting girls to stay in school is one of the most effective ways to prevent early marriage and early maternity. Education is also a fundamental factor in accelerating the demographic transition to lower birth and death rates" (page 3) 
physical abuse, etc., received by his female neighbor from her partner ${ }^{9}$.

The space becomes a container and naturalizes violence, people live it directly or indirectly, without being clear about how to react to it. Silence is established as a normalizing element and in turn a controller of actions. When the cries of mistreatment of a female neighbor, caused by her husband occurs, silence appears. This established way of "responding" to violence is also evidenced in other expressions of violence, for instance, when there are shootings or robberies. ${ }^{10}$ According to the United Nations Population Fund (UNFPA) ${ }^{11}$ in urban areas, women may be at greater risk of gender-based violence because neighbors are less likely to intervene.

Violence against women is not foreign to participants' experiences,. From their narratives, they locate gender-violence everywhere from community spaces to the most intimate and familiar spaces,

9 In relation to the human settlements and shelter, the IASC states: "Excessive occupation, lack of privacy or locks, insufficient lighting, poor distribution of non-food items and construction of shelters in unsafe places increase the risk of domestic violence, sexual assault, harassment, sexual exploitation and other forms of gender violence, of which women and girls are victims especially. " (IASC, 2015, page iii)

10 Nota $\mathrm{N}^{\circ} 020$ : se recomienda al autor revisar la frase para crear un mayor sentido de cohesión y fluidez.

11 See ONU Hábitat, Igualdad de Género para Ciudades más Inteligentes. Desafíos y Avances, p. 12. (In Spanish) it does not seem coincidental that in the symbolic cartography created by the participants, while girls talked about their homes as places of peace, female and male adolescents identified only their bedrooms as a space of peace, free of violence. Another element highlighted mainly by adolescents was that of female hyper-sexualization, and aesthetic stereotypes about women's bodies. The constant media bombardment sells us the idea of female bodies with characteristics that could even be point out as distant to the ways in which bodies are constituted in our Latin American societies, from skin color, hair or eyes, to hip size or height; all these inconsistencies contributing to the continuous laceration with which many women establish a dialogue with their bodies.

The obsessive handling of the body in terms of beauty canons, generates among these young women internal struggles when the canon does not represent them or when they face being laughed at from their peers because of their physical appearance. One of the young women, in her reflection on the different forms of violence, pointed out that there is a "discrimination due to obesity", who, when asked about it, narrated the ways in which "obese" women are constantly teased, and how this can lead them to bulimia or anorexia. 
Also identified in female adolescent participants is a discourse that evidences the construction of affective dependence patterns with their partners. This feeling of dependence is fueled by the songs they sing and dance, by female characters of Mexican and Colombian soap operas (telenovelas) so well liked by them, even the life experiences of their mothers, sisters, aunts, friends; all this is reflected in the activities developed throughout the sessions. Comments like, "she feels lonely because her boyfriend left her" coming from a 14-yearold female adolescent or "my dad left my mom", "abandoned her", have been recurrent throughout the process. In this sense, it is evident how the construction of affective bonds with potential partners, friends and peers stems from emotional deprivationand fear of being abandoned, situation that can push women to assume submissive roles and subordination in their relationships.

In summary, unlike other forms of violence, such as violence against nature, violence against women in its multiple expressions (physical, sexual, psychological, patrimonial, structural, etc.) was present in all the symbolic cartographies created by the participants. Their stories illustrate the cruelest forms in which these forms of violence cross the bodies of women, and in a broader sense, the bodies of all individuals participating in the project, men and women, who live in these spaces and are fueled by them.
Thinking of "peace" from abstraction can lead us to idealizations, states of purity, impossible for human beings to reach, or it can lead us to overlook and devalue those actions that allow us to construct, from our subjectivities, forms of peaceful coexistence. Peace or "peaceful ways" are constructed through personal as well as collective processes, from the most intimate and minuscule spaces to those that extend to the public, local, and community spaces. Peacebuilding is, in any case, an exercise where all the people of the community participate, wherein community is understood not as the neighborhood, but as a collection of human beings who coexist and live in different spaces, in which a common identity is built around common values.

In this sense, one of the objectives of this project is aimed at not only having participants identify forms of violence, but also have them recognize forms of peace present in their communities, based on the premise that not everything is completely negative or violent in certain spaces in spite of the stereotypes and stigmas associated with the people of Guararí and the reinforcement of these by the media and other institutions. As mentioned before, these stereotypes are widely recognized by the participants. In fact, for a young boy, the very act of participating in the Building Zones of Peace Project, constitutes a way of informing others that in 
Guararí one finds educated, hard-working people, "good people" (Male teenager, 13 years old).

From the experienced process, two important analysis elements stand out for our reflection regarding the perceptions of the participants. On the one hand, as effectively noted in the previous paragraph, both girls and adolescents recognize spaces smeared with many expressions of violence but also recognize in them ways of living in peace. The experience of "living in peace" is identified in day-to-day level situations which breaks away from the erroneous ideas that peace is the absence of violence or the concept of peace as an abstract idealization. In this way, participants express sensations of peace both from a plantain plant growing on a sidewalk in front of one participant's house, as well as from more structured spaces such as the community school.

A second element to underline would be the conceptualization of peace, made by girls and adolescents. In the task of constructing notions of peace, participants recognize spaces where peace is lived, as those spaces that protect and guarantee them fully experiencing their human rights; this is how a school or healthcare center represent a space for learning (right to education) and a space for attention when they become sick (right to health), respectively. This can be evidenced in other spaces identified by the participants, the greengrocery store that provides vegetables and fruits (right to a healthy diet), or the children's playground associated with their right to recreation.

In addition to the above, participants recognize the spaces as guarantors of rights not only on a personal level but also for the needs of other members of the community, an example of this is that they identify the public bus service as a space of peace, not only because it allows them to travel to different places, but also, and of special relevance, they point out that how buses equipped with ramps for wheelchair users creates a great sense of peace in them. The same occurs with the Casa de la Mujer, identified as a place that helps women in the community.

Both girls and participating adolescents recognize the Civic Center for Peace (CCP), as a space where they experience peaceful forms of coexistence. An exercise is evidenced of appropriation of spaces offered by the CCP including areas for practicing sports such as soccer (football), or spaces for reading such as the library, a female participant tells us, "I like the library because I learn, and I have peace while reading". (Girl, 7 years old).

Finally, the CCP constitutes a space where minors can bond with their peers, build affective relationships of respect, solidarity, and equality, it is a space 
that allows them to withdraw from the normalized violence experienced daily, either at the pulperia ( grocery store) or in the corner where assaults with firearms is commonplace, the drug dealing spot, or at home where screaming and physical abuse is present. One of the girls refers to the CCP in the following manner: "Here I have the possibility of sharing with people, when I am sad and when I am happy". (Girl, 9 years old)

The repercussions of violence on the lives of girls, boys and adolescents of Guararí have a high personal, family and social cost in terms of psychosocial affectations such as depression, anxiety, hyperactivity, increase in aggressive behaviors, school under performance, alcohol and substance abuse, gang affiliation, commercial sexual exploitation, human trafficking, among others; all the above fuel cycles of violence, perpetuating poverty and social exclusion.

Based on the narration of their experiences and perceptions about violence, we can trace the state of vulnerability in which many of these people find themselves, mainly if we consider that many live forms of violence in spaces that should be safe, such as their own home. Being home determinant in the development of such behaviors, families that face conflicts with physical violence and shouting, that lack tools for dialogue, that construct deficient and weakly affective bonds, all increase the chances of young people being trapped in these violent cycles.

It is important to insist, as previously stated, that the construction of these people's personality and identity is branded by inequality, discrimination and stigmatization and, therefore, the tendency to violent behaviors appears to be a form of protective shield against the violence imposed on them.

The violence of a polluted environment (nature) and a contaminated and disordered urban space foist and add to the economic scarcity, resource shortage, few stimuli and lack of institutional attention, are all factors that create a growing discontent and disillusionment in communitarian management possibilities and the public offices' good intentions. These discontent and disillusion becomes more palpable at a greater participant age, situation that becomes more distressing as it seems to inhibit creative and imaginative possibilities for the construction of less violent communities by this population.

In this sense, the CCP achieves its goal of becoming a center of peace and creation of alternatives for minors. The construction of an active and positive citizenship is a fundamental challenge of the CCP in Guararí, a construction that in some ways would encompass the gaps left behind by institutions. The people participating in the project have 
found in the CCP a space where they are formed as subjects of rights, critical and reflective of their reality, of the reality of their families, the community and the country. Likewise, they learn to coexist in a horizontal and respectful and interdependent environment, paying to the social fabric.

Lastly participants are aware that peace is not an absolute and they capture this in their photographs, peace is intertwined and coexists with violence, nonetheless, they understand this complexity from daily situations, finding in the smallest of elements peaceful forms of coexistence. In this sense, both the facilitators and the students of IDELA's Master of Human Rights and Education for Peace programme walked side-by-side with the girls of the Sepro Joven program and the adolescents involved in the Building Zones of Peace Project and in this journey we find in this creative and imaginative population group, an exercise of deep reflection around the space of Guarari engaging on issues ranging from affective, solidarity and collaborative principles, dialogue, games, laughter, from embracement.

\section{References}

Bauman, Z. (2001). La Globalización, consecuencias humanas. México: FCE. (In Spanish).
Chaves, L. (2014). Diagnóstico 2014. Heredia: Centro Cívico por la $\mathrm{Paz}$ Guararí. Documento interno de trabajo. (In Spanish).

De Sousa Santos, B. (2006). Conocer desde el Sur. Para una cultura política emancipadora. Perú: UNMSM. (In Spanish).

Galtung, J. (1998). Tras la Violencias, 3R: reconstrucción, reconciliación, resolución. Afrontando los efectos visibles e invisibles de la violencia. España: Gernika Gogoratuz. (In Spanish).

Grillo, M. (2014). Modelo base de atención Centros Cívicos por la $\mathrm{Paz}$ (CCP). Ministerio de Justicia y $\mathrm{Paz}$, San José. (In Spanish).

Herrera Flores, J. (2008). La reinvención de los derechos humanos. Andalucía: Editorial Atrapasueños. (In Spanish).

IASC. (2015). Guía temática Directrices para la integración de las intervenciones contra la violencia de género en la acción humanitaria: Reducir el riesgo, promover la resiliencia e impulsar la recuperación. Recuperado el 5 de febrero de 2018, de Global Protection Cluster: https://gbvguidelines.org/wp/wp-content/ uploads/2016/03/GBV_TAG_ SPANISH_SHELTER-021916. pdf (In Spanish). 
Lederach, J. P. (2007). La imaginación moral. El arte y el alma de la construccion de la paz. Bilbao: Gernika Gogoratuz. (In Spanish).

Lopez, S. (2011). Prácticas de justicia restaurativa para una cultura de paz. En U. p. Paz, Desarrollo Profesional para Construir una Cultura de Paz (págs. 309 - 406). San José: UPAZ. (In Spanish).

Obando, A. (2011). Educación género sensitiva: Paradigma de una cultura de paz. En UPAZ (2011) Desarrollo profesional para construir una cultura de paz. San José: Universidad para la Paz. (In Spanish).
ONU-HABITAT. (2010). Igualdad de Género para Ciudades más Inteligentes. Desafíos y Avances. Nairobi. (In Spanish).

UNESCO. (2013). Informe de Seguimiento de la Educación para Todos en el Mundo. Ficha Descriptiva. Accesible en: https:// es.unesco.org/gem-report/sites/gem-report/files/girls-factsheet-sp2.pdf. (In Spanish). 